\title{
Lopingian tetrapod footprints from the Venetian Prealps, Italy: New discoveries in a largely incomplete panorama
}

Lorenzo Marchetti, Matteo Belvedere, and Paolo Mietto

Acta Palaeontologica Polonica 62 (4), 2017: 801-817 doi:https://doi.org/10.4202/app.00392.2017

After new studies were carried out in the Lopingian Val Gardena Sandstone of northern Italy, in the Recoaro area

(Venetian Prealps, NE Italy), the following tetrapod ichnotaxa are identified: cf. Capitosauroides isp., cf. Merifontichnus isp., Pachypes isp., Paradoxichnium isp., and Rynchosauroides isp., probably corresponding to ?parareptile, captorhinid eureptile, pareiasaurid parareptile, archosauromorph neodiapsid, and lacertoid neodiapsid trackmakers, respectively. An undetermined track shows features consistent with possible therapsid producers. These are the first possible records of Merifontichnus and Capitosauroides in the Lopingian (late Permian) and one of the few records of Paradoxichnium worldwide. The paleoecology of the ichnoassociation highlights a relatively high diversity in the floodplain lithofacies, a monospecific association of Rhynchosauroides in distal floodplain/sabkha environments and the occurrence of Paradoxichnium isp. and cf. Capitosauroides only in the lagoon lithofacies, suggesting different habits of the trackmakers. The tetrapod ichnoassociation is characterized by eureptile and parareptile tracks, and differs from the classic Lopingian tetrapod ichnoassociation of the Dolomites mainly because of the absence of chirotheriid and small parareptile ichnotaxa. A comparison of the Italian tetrapod ichnoassociation with other Lopingian non-eolian ichnofaunas suggests a possible preference for marginal marine settings by the archosauromorph and therapsid trackmakers at low-latitudes of Pangaea.

Key words: Tetrapoda, footprints, paleoecology, Lopingian, Val Gardena Sandstone, Venetian Prealps.

Lorenzo Marchetti [lorenzo.marchetti85@gmail.com], Urweltmuseum GEOSKOP, Burg Lichtenberg (Pfalz), Burgstrasse 19, D-66871

Thallichtenberg, Germany. Matteo Belvedere [matteo.belvedere@jura.ch], Office de la culture, Section d'archéologie et paléontologie, Paléontologie A16, Hôtel des Halles, P.O. Box 64, 2900 Porrentruy 2, Switzerland. Paolo Mietto [paolo.mietto@unipd.it], Dipartimento di Geoscienze, Università degli Studi di Padova, Via Gradenigo 6, 35131, Padova, Italy. 
This is an open-access article distributed under the terms of the Creative Commons

Attribution License (for details please see creativecommons.org), which permits unrestricted use, distribution, and reproduction in any medium, provided the original author and source are credited.

Forif Full text $(1,854.0 \mathrm{kB})$ 